\title{
Rural Livelihood Perception on Climate Variability/ Change- A Case Study for Kachchh Region, Gujarat
}

\author{
Jagruti P Shah* \\ Earth and Eco-science Research Institute, India
}

Submission: April 24, 2018; Published: May 30, 2018

*Corresponding author: Jagruti P Shah, Earth and Eco-science Research Institute Mundra Road, Bhuj- Kachchh, Gujarat, India, Email: jhsphd@gmail.com

\begin{abstract}
Kachchh climate is diverse and changing. Kachchh is facing the challenges to sustain of rapid economic growth, urbanization and dealing with the global threat of climate change. This study was conducted in Kachchh district of Gujarat state. Climate change threats are from accumulated green house gases emission in the atmosphere, intensive industrial growth and high consumption lifestyle adopted from developed countries. Due to this changes pressure comes on natural resources and adversely affect the livelihood of rural people. For this study two different sites of Kachchh were selected i.e. dry land (Kanmer) and wetland (Jakhau, Tunda wandh and Mohadi wandh) villages. The field work is done between the January 2016 to January 2017. For this study, we have taken the perception from various livelihood holders i.e. Men, Women and Youth We have collected the detailed livelihood information from each livelihood holder from and taken the information of more than 100 peoples from both the village sites. This paper aims to improve our understanding of local people's perceptions of these changes, explore the ways they are affected by climate change and how well they are adapting to them. In order for policymakers to plan responses to climate change in India, it is essential to understand how people understand and fight for their livelihood and cope with these trends. The research showed that most respondents had a clear understanding of what was directly affecting their lives and livelihoods in terms of changing climate trends and the wider environment over the long term. Most respondents were also aware of the usually limited options available to them to adapt to the changes they experience. However, the respondents were less able to understand differences between climate variability and climate change or the causes of the trends they observed.
\end{abstract}

\section{Introduction}

Recently, issues of climate variability and change have been on the front burner of society's environmental discourse the world over. This is because of the precarious state of the global environment which is now possessed by eminent unpredictable weather conditions resulting in climate variability and change. India, which faced drought conditions at least once every three years over the last few decades, is amongst the most vulnerable and drought prone countries in the world [1]. Since the mid1990s, India has been experiencing prolonged and wide spread droughts in consecutive years, with increased requency in recent times $[1,2]$. It is now well accepted that droughts will pose an increased threat to climate sensitive economic sectors in India, especially agriculture [1]. About two-thirds of India's population depends on agriculture and allied activities, hence drought event sare likely to threaten the overall economy of the country. The agriculture in India is primarily dependent on South west monsoon rainfall (i.e., on average $80 \%$ of annual rainfall occurs between June and September) [3]. Due to the temporal and spatial uncertainties of monsoon rainfall, Indian agriculture is at risk.

The Indian Meteorological Department (IMD) defines meteorological drought as a situation when rainfall over an area is less than $75 \%$ of the climatological normal. The climate of this district is characterized by hot summer and dryness in the non rainy season [4]. As per climatological data a rainfall deficiency of $25 \%$ but some villages were not getting the rainfall as per IMD norms. Therefore this strategy is not useful in Kachchh like drought prone region because the area of each taluka is very big and everywhere rainfall is variable. This has become critical because climate change will significantly affect production of farmers, livestock keepers, fishers and forest-dependent people, particularly in areas with persistent soil and water scarcity, high exposure to floods, droughts, which increases poverty and hunger [5]. Recurring drought is a major challenge in the Drought Prone Area of Kachchh district. In Kachchh, the rural population is largely dependent on agriculture, especially rainfed and groundwater-irrigated crop production. Kachchh district supports 1.7 million livestock, and ranks $12^{\text {th }}$ in the state's cow milk production and $1^{\text {st }}$ in the wool production. The livestock keeping is the second livelihood option of the local population after agriculture. The pressure on the existing grazing land is increasing with the rise in livestock population. The grazing land in Kachchh has declined from $34,46,900$ ha in 1960-61 to 12 , 04,211 ha in $1970-71$ (i.e. $65 \%$ ) [4]. Further, these grasslands have the problem of Prosopis juliflora invasion. 
The objective of this study is to understand the rural farming and pastoral and fishing community's perception of drought and climate variability/change impacts on their socio-economic activities and environment, their adaptation at the household level and opinions on government climate variability mitigation measures.

\section{Study Area}

Kachchh is the second largest district in the country, covering a total area of $45,652 \mathrm{~km}^{2}$ and located in the north-western region of Gujarat state. Kachchh district stretches between 220 $41^{\prime} 11^{\prime \prime}$ to $24041^{\prime} 47$ " N latitude, and between 680 9' 46" to 710 54' 47 E longitude. The district shares its international boundary in the north and north-west with Pakistan, whereas the Arabian Sea lies in the west and south-west and the land area on the southern side is limited by Gulf of Kachchh. Rajkot is sharing its eastern boundary, while Bananskantha, Mehsana and Rajasthan state form the part of north-eastern boundary. Administratively, this district encompasses 10 talukas with 950 villages within it Figure 1.

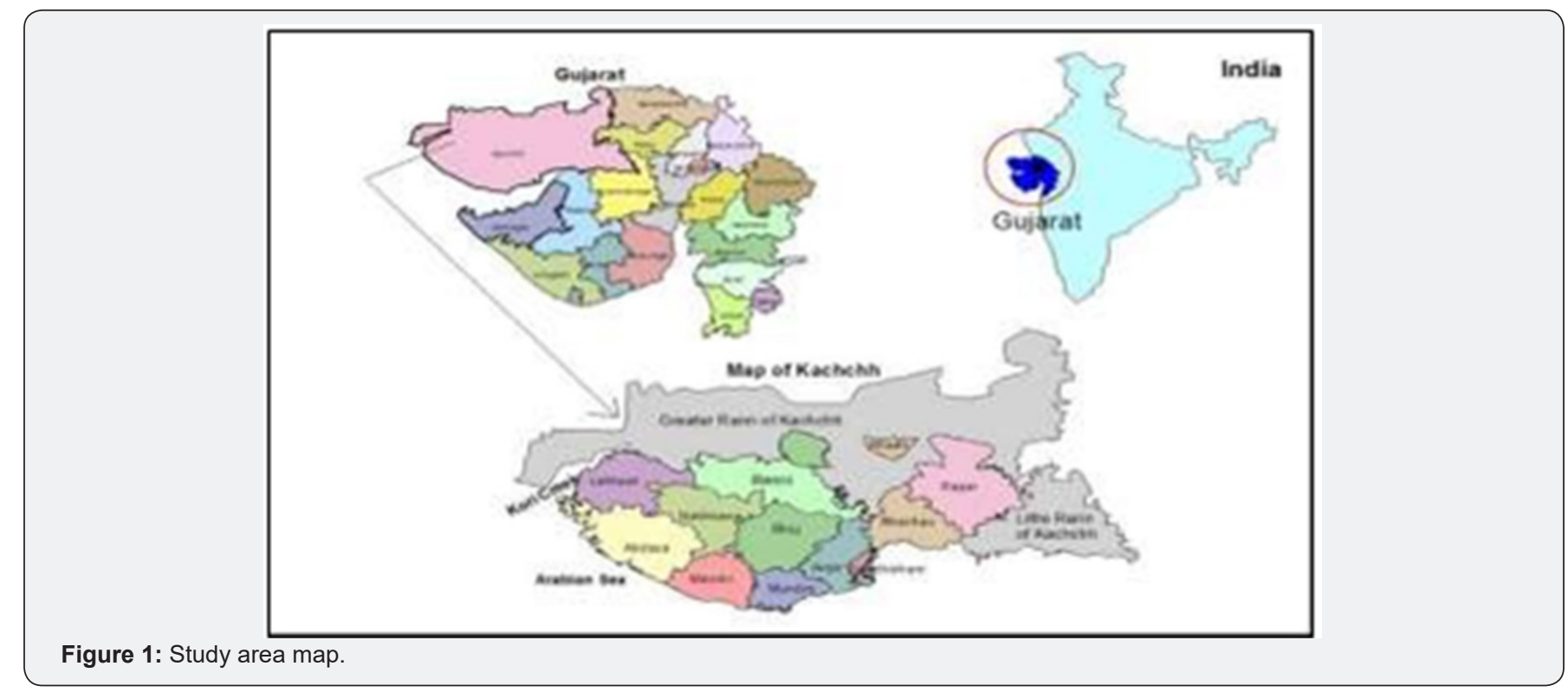

In Kachchh two sites were selected wetland and dry land area. During the survey Jakhau (village, ashira wandh and jakhau port) from abdasa taluka, Mohadi wandh from Lakhpat taluka and Tunda wandh from Mundra taluka are wetland sites and dryland area, Kanmer village and surrounding six wandhs from Rapar taluka. In the wetland site people's occupation were more focuses on fishing, fish exporting, livestock holder and agriculturist. In jakhau two types of fisherman are there "Pagadia" (they are from Kolly community) and other are having their own boat mostly they are from Muslim community. At Jakhau port, many other coastal areas fishermen were also coming with their boat i.e. trollers and export the fishes to various countries i.e. UK, Europe and parts of India. The second site is Kanmer and surrounding six wandhs, dryland area and people are engaged in agriculture related occupation. Being an arid Kachchh district, most of the wetlands in Kachchh are seasonal where the rainfall is the major source of water. Wells are very less and their water level goes very down near to saline. Present study focuses on the rural people's perception about global warming and due to the climate variability changes are comes on their livelihood. What are the changes they did in their livelihood from past 20 years or after the earthquake?

\section{Geomorphology of the Area}

Jakhau coast is the westernmost segment of Kachchh coast. The region was under marine flooding and submergence during the middle Holocene high sea level indicated by the rocky cliffs of $10-15 \mathrm{~m}$ high and stabilized coastal dunes. However, tectonic uplift of the region in the recent past indicated by the raised mudflats, abandoned rocky cliffs, and the incised fluvial terraces along the rivers [6]. Kanmer site is a village of Rapar taluka. Kanmer locally known as Bakar Kot, is an archaeological site belonging to Indus valley civilization.

\section{Climate and Isohytes}

Kachchh climate is unique in Gujarat State as it is surrounded by Arabian Sea in the south and the harsh Rann in the north and eastern boundary. The higher evaporation in the Rann area influences the microclimate of the mainland making it arid and the cool sea breeze makes it more comfortable weather in the coastal regions. The climate of this district is characterized by hot summer and dryness in the non rainy season. An isohytes of Kachchh region (developed based on the rainfall data till 1986) show that there is decline in rainfall as one moves towards the west. Lakhpat taluka at the western end of Kachchh receives the least amount of rainfall in the district Figure 2. 


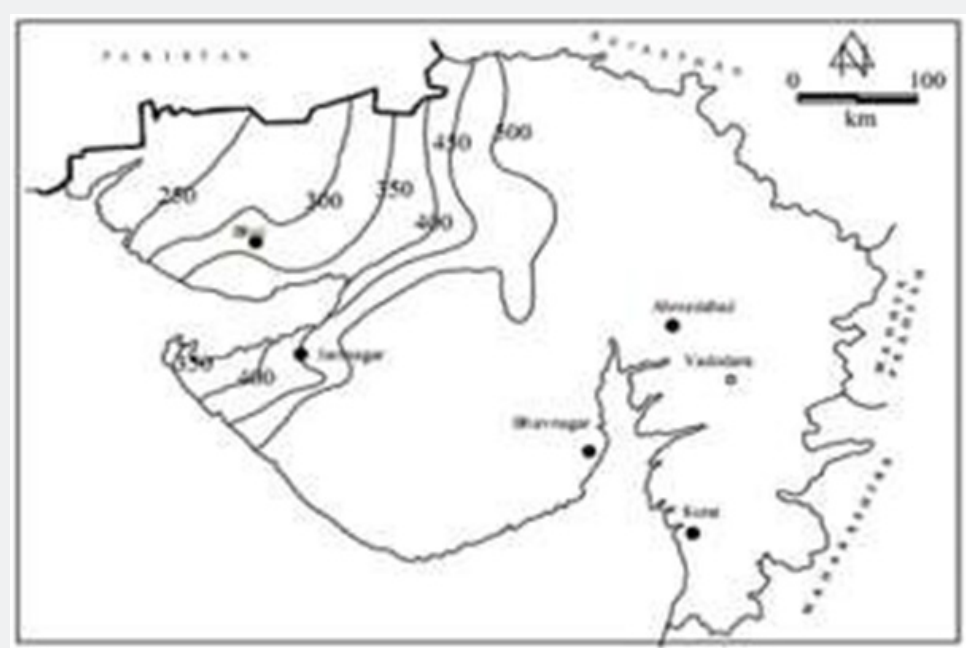

Figure 2: Isohyte (in $\mathrm{mm}$ ) for Kachchh region. source -eco regions of Gujarat (GEC).

\section{Objectives}

i. To assess existing knowledge on climate change

ii. To understand the local people's perceptions towards local climate change

iii. To find out the major impacts of climate change in local peoples view

iv. To indentify perceived adaptation barriers

\section{Methodology}

Methodology is same for both the sites. Field survey was carried out for socio economic study to understand the climate change impacts and pressure on people's occupation and their perception about adaption during these changes. Men and Women both were selected and consulted for the data collection. To assess their perceptions on climate variability/change by way of local communities, overall l metrological scenario (i.e. climate, rainfall, wind flow, drinking and agricultural water, droughts) as well as major livelihood and overall lifestyle of the village. We collected the information on wells and surface water sources, villager's occupation, crop pattern, major crops, livestock population, disease in livestock due to variables in temperature, any plant or animal species degradation and also their traditional knowledge about their occupation following methods were used.

\section{a. Group and team dynamics (discussion and meetings) \\ b. Interviewing and dialogue (Individual old age male and female, village headman, asha worker etc.) \\ c. Local Ngo views}

This finding provided good information with the respondents views on several issues. For their livelihood and occupation changes this a comparative sense of the present and past condition is an essential tool which will help us to understand its degradation/improvement through time.

\section{Results and Discussion \\ Climate change knowledge}

The data collected from 100 respondents and out of that only five people have herds the word and knowledge about climate change. Only educated people know the word global warming and Climate Change residents of selected villages. Respondents accept that their climate has significantly changing. Both the village peoples have full understanding of long-term changes in climatic parameters such as Increased / warmer temperature, Change in quantity and intensity of rainfall, Stormy weather, Once in a every three year drought, Longer dry seasons, More cold but it is for few days, all seasons are changing, Less moist in season etc. Other identified parameters such as long term shift in wind speed, change in rainfall intensity and uncertainty of rain.

\section{Agriculture}

The result shows that as per the view of small and big agriculture land holders given the following reasons for the impact of climate variability. Due to the variability in climate Crop wilting, more pest and diseases, quality of production decreased, increased irrigation requirements and decrease in soil fertility. Some farmer made changes in their traditional crop patterns as well as major crops. Due to the climate variability/ change Prosopis juliflora (ganda baval) is increases.

\section{Livestock keepers}

The result shows that due to the uncertainty and variable in climate livestock's having more diseases and they become weak. Due to the uncertainty in rainfall decreased milk production of the cattle. The results also show that the cattle work efficiency decreased and they face difficulties during delivery. A result also shows that increase disease in livestock due to variables in temperature and water shortage. 
Overall Impacts identified due to climate variability/ change in wetland sites is less fish production therefore all the fish beds are empty at Jakhau and also fish varieties decreased. Due to the uncertainty wells and water resources are less flooded and also early dried therefore drinking water shortage in both the sites Figure 3.

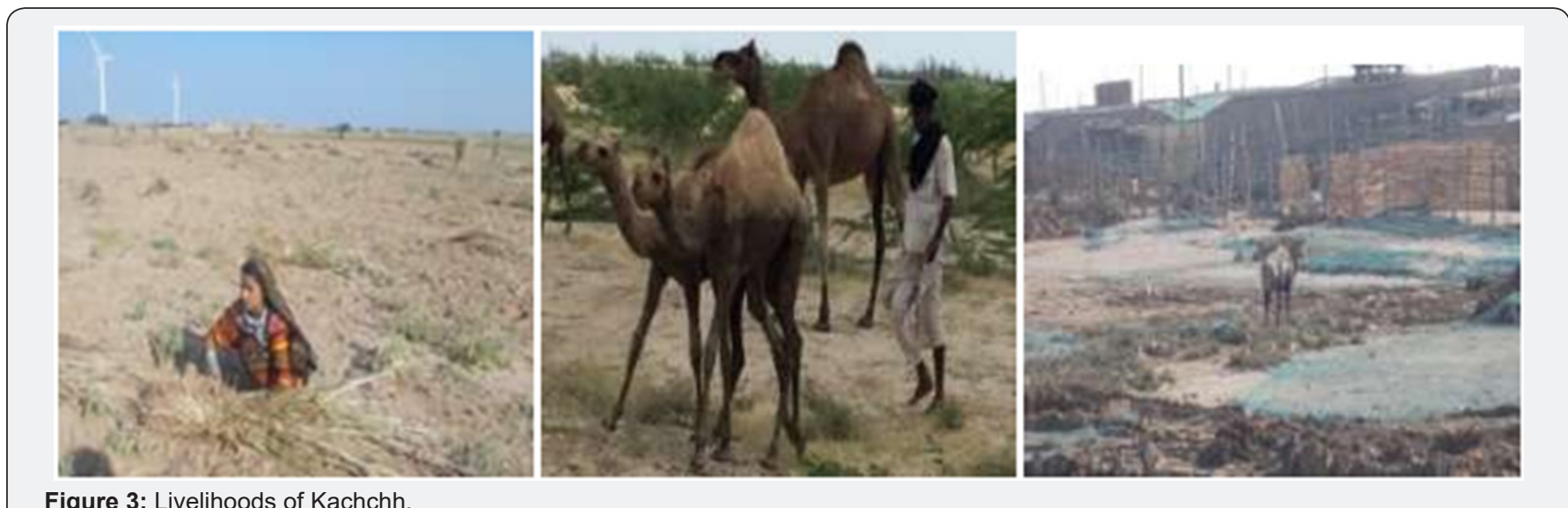

\section{Perception -attitude of peoples}

As per local people's perception major causes are deforestation and burning fossil fuel i.e. Plastic and carbon emission increases air pollution. Some of the respondents given the reason for uncertainties are they used more pesticides and Nitrogen fertilizers in farm. Some respondents stated that now a day's people adapted modern life style that also a one of the reason. Some respondents asked that due to our "bad karma" and now only GOD should be appeased, Most of respondents give the reason behind this climate variation / change is real and it is a global issue and that require urgent attention. Few people stated that only scientist should be concerned about this issue.

\section{Perception -Risk on Livelihood (Agriculture, Fishing)}

\section{Traditional livelihood changes}

As per the respondents farmer's perception of risk is moderate to high for their livelihood. Due to climatic parameters changes crop disease and agriculture investment may increase therefore farmers spending is more but return income will be uncertain. As per small agriculture land holders, if they want to work as an agricultural laborer getting employment in bigger farm will become uncertain. Some of the agriculture holders migrate from village to company or at urban area for employment. Agricultural workers were cutting and selling firewood instead of growing crops. People who had assets, such as land or livestock, were better able to fund small businesses as they changed their livelihoods. Others who had few assets were more likely to work as agricultural day laborers on other people's land. They are interested in cash crops varieties. They engaged in transport work such as working in brick-making factories, cutting wood, or driving rickshaws.

As per fishermen perception risk is very high for pagadia fishermen, because they won't get fishes from creeks. All the fishermen clearly suggest that fish catching and exporting business is very less due to the uncertainty in climate. Due to less fish availability fishermen changing their occupation and engaged in charcoal making, wood cutting or agriculture laborer

\section{Discussion on Findings}

Investigation show that majority of community members expressed awareness of climate variability and change through perceived longer dry seasons, low rainfall, increased/warmer temperatures and so on in recent times. It is difficult to assess the level of understanding that respondents had about global climate change trends. In general, respondents confused climate change and climate variability. Some focus group respondents reported that a lack of understanding of the nature of climate change. The meteorological parameters also prove the point of climate variability.

\section{Climatic Variability and Vegetation}

The annual mean maximum temperature of Gujarat has increased by $1{ }^{\circ} \mathrm{C}$, the annual mean summer temperature by $0.7^{\circ} \mathrm{C}$ and the mean winter temperature by $1.2^{\circ} \mathrm{C}$ for the past 50 years (1957-2007) along with increase in the extremities of weather like heavy rainfall, accompanied by sudden burst and episodes of droughts and floods [4]. Rise in temperature would require more water for the plants due to high rate of evapo-transpiration in the arid region leading to higher salinity and desertification [7]. Changes in temperature and rainfall have significant impact on production of fruits, vegetables and medicinal plants. There are studies indicating that $1 \mathrm{oC}$ increase in temperature may reduce yields of wheat, soybean, mustard, groundnut, and potato by 3-7\% [8]. Tree phonological observations have proved to be most effective impact indicators of climate change [9], as many species are highly sensitive even to the smallest change in the long prevailing climate of any ecosystem [10]. As per the singh, 2015 importance of roadside vegetation and diversity in 
enhancing carbon sequestration and if managed judiciously can play an important role in climate change mitigation.

\section{Adaptation}

The study finding shows that respondents are adapted following things for livelihood and employment. They are taking crops in rotation and most of farmers taking a castor crop. They change their farming near irrigation water availability [10]. They are using hybrid and latest technology i.e. Hybrid seeds, drip irrigation, deepen wells/bore wells, use of tractor. Some rural people change their livelihood and work as a laborer. They are interested to take off farm job. They are migrating to urban areas and taking job in company. Now they are investing less in farm and consume also less. They decrease and or change number and types of cattle. Very few farmers are buying crop insurance.

\section{Mitigation}

There is need to recharge the ground water and have maximum utilization of the runoff to sustain agriculture and human need. Ground water is the major source of fresh water in Kachchh and dependency on ground water would increase in years to come $[11,12]$. Creation of fresh water barriers by recharging ground water in the coastal aquifers to prevent salinity ingress is essential. Creating larger storage capacity is in the existing dams to mitigate the water shortage.

We cannot adapt to what we don't know because successful adaptation requires information and understanding of future change, information on climate change should be made available to farmers and other natural resource users to create more awareness and the knowledge on further effects of some human activities (such as bush burning) that contribute to climate change. For mitigating to the climate change reduction in the use of Non Timber forest product (NTFP) and also reduced the use of timber/ fuel wood. Plant more trees to mitigate the climate change. Importance of roadside vegetation and diversity in enhancing carbon sequestration and if managed judiciously can play an important role in climate change mitigation.

\section{Recommendations}

i. Encourage rural people on alternative occupations and sources of income

ii. Land use planning should be part of any interventions programme on climate change as land use change constitutes the greatest driver of deforestation.

iii. Capacity building programme is vital to strengthen climate change adaptation especially in rural areas.

iv. Participatory adaptation strategy that involves local farmers in decision making and planning will ensure cooperation of local people in climate change adaptation.

v. Indigenous knowledge system should complement global modern knowledge systems to enhance climate change mitigation. vi. Climate change and adaptive mechanism should be integrative including all other sectors of the economy in the course of planning.

vii. Focus on local research and improve the capacity of local communities and combine traditional knowledge by joining them in local disaster plans

viii. Awareness/Education on the issues of climate change still needs to be created to expand the level of awareness.

ix. Better communication means more awareness should be created on the effect of human activities on climate; environment education need to increase by media i.e. audio and video and give the knowledge about Govt. schemes i.e. crop insurance, weather and climate forecast in mobile

\section{Conclusion}

This study assessed the perception level of rural people to climate variability/change in rural communities in the Kachchh region of Gujarat State. The communities were selected from dry land and wetland sites with the back ground of their occupational homogeneity, cultural and traditional lifestyles and sources of livelihood.

Rural people to a large extent are aware of the dynamics of their local climate; they are aware of climate variability/change issues and have strategies/coping mechanisms. The traditional knowledge practices have been adopted by the people in adapting to climate change impacts among farmers in area. This generates concern for behavior change and perception in this regard [12]. Notwithstanding, there is the need to synergize local and modern mitigation measures. Moreover, people to be responsible as part of the effort to reduce the trend through a review of our life styles. This change will only require a systematic and lasting effort through education and awareness of the people as education here seems the safest way to achieve the desired success. This is done not only by giving the people information, but ensuring that awareness is mobilized to the grass root to re-orient the society towards best/sustainable practices through attitudinal change.

\section{Acknowledgement}

I respectfully acknowledge to Dr. Lyla Mehta and Dr. Shilpi Shrivastava, University of Sussex, for providing me financial support for climate change study of Kachchh region. I gratefully acknowledge Dr. V. Vijaykumar Director Gujarat Institute of Desert Ecology, Bhuj for supporting during the study period. The project 'Climate Change, Uncertainty and Transformation' was funded by the Research Council of Norway (Grant no: 235449).

\section{References}

1. http://www.moef.nic.in/downloads/others/Vulnerability_PK\%20 Aggarwal.pdf.

2. Rathore A, Jasrai YT (2013) Impact of climate change on the trees of gujarat, india: phenological perspective. Indian Journal of Fundamental and Applied Life Sciences 4(4): 438-447. 
3. (2002) India Meteorological Department. South west monsoon 2002 end of season report.

4. GES (2011) Trends of changing climate and effects on Eco- environment of Gujarat, India.

5. Huq S, Rahman A, Konate M, Sokona Y, Reid H (2003) Mainstreaming adaptation to climate change in least developed countries. Climate Policy 4(1): 25-43.

6. Maurya DM, Thakkar MG, Patidar AK, Bhandari S, Goyal B, et al. (2008) Late Quaternary geomorphic evolution of the coastal zone of Kachchh, western India. Journal of Coastal Research, 24(3): 746-758.

7. Kumar A (2009) Reclaimed islands and new offshore townships in the Arabian Gulf: potential natural hazards. Current Science 96(4).
8. Kushwaha CP, Singh KP (2008) India needs Phenological Stations network. Current Science 95(7): 832 -834.

9. Anonymous (2009) Impact of Climate Change on the vegetation of Nainital and its surroundings. NBRI Newsletter, India, 36: 25-31.

10. FAO (2013) FAOSTAT. Food and Agriculture Organization of the United Nations.

11.GES, GUIDE, MSU (2002) Conservation of Rare and Endangered Biodiversity of Gujarat. Gujarat Ecology Commission. Vadodara, India, p. 393.

12. Kaushal S (2015) Genda Singh Roadside vegetation diversity of Jodhpur district and its role in carbon sequestration and climate change mitigation. Advances in Forestry Science 2(2).

Your next submission with Juniper Publishers will reach you the below assets

- Quality Editorial service

- Swift Peer Review

- Reprints availability

- E-prints Service

- Manuscript Podcast for convenient understanding

- Global attainment for your research

- Manuscript accessibility in different formats

(Pdf, E-pub, Full Text, Audio)

- Unceasing customer service

Track the below URL for one-step submission https://juniperpublishers.com/online-submission.php 